\title{
Solo Craft Gallery Expo dengan Pendekatan Arsitektur JaWa Kontemporer
}

\author{
Betyona Bioza ${ }^{1}$, Titis Srimuda Pitana ${ }^{2}$ Gunawan $^{3}$ \\ Program Studi Arsitektur, Fakultas Teknik, Universitas Sebelas Maret ${ }^{1}$ \\ Email: beebioza@gmail.com \\ Program Studi Arsitektur, Fakultas Teknik, Universitas Sebelas Maret ${ }^{2}$ \\ Program Studi Arsitektur, Fakultas Teknik, Universitas Sebelas Maret ${ }^{3}$
}

\begin{abstract}
Solo Craft Gallery Expo is an effort to accommodate the presence of creative industries joined in the craft subsector SMEs, and facilitating MICE activities in the city of Solo. The space is in the form of art galleries as well as a market for good packaging and expo space with diverse capacities. Combining the two functions of this building is a strategy for mutually supporting each other's existences. Gallery space presented as cultural charms, while the expo space plays a role in bringing visitors. The government policies in synergy with the city's potential efforts to support and facilitate the development of the city for more advances physical quality and human resources. This system if it is associated with the city of Solo as location, intersects with the image which is the city of culture. This last issue is associated with contemporary architecture, which is an effort to locate and revive the values of cultural and society, as a reflection of the city's identity. In this case, the Javanese architecture which is the local architecture and result of the Javanese cultural community life, deserve to be appreciated to exist as a force of local architecture. The process of aligning the image of the building with the city image of the building of Solo Craft Gallery Expo, carried out through the application of contemporary Javanese Architecture.
\end{abstract}

Keywords: MSME craft's sub-sector, craft galleries, MICE facilities, contemporary Javanese architecture.

\section{PENDAHULUAN}

Solo merupakan sebuah kota dengan keberagamaan dalam perkembangan tradisi. Memiliki sejarah panjang dengan potensi keberagaman keraton dan juga proses akulturasi etnis, yaitu: Cina; Arab, dan Belanda. Dengan akar tradisi yang kuat, Solo tumbuh dengan perpaduan antara tradisi lokal dan tuntutan perkembangan sebuah kota modern. Dengan segala keterbatasannya, masyarakat justru berproses kreatif, mengembangkaan apa yang mereka punya sebagai upaya untuk bertahan hidup sekaligus mempertahankan tradisi. Mulai dari kuliner, seni pertunjukan, kemampuan mereka dalam membuat sesuatu (keterampilan), arsitektur, dan lain-lain.

Data Dinas Koperasi dan UMKM tahun 2015 menunjukan 2.796 pelaku industri kreatif dengan berbagai subsektor yang tersebar di Lima kecamatan. 820 di antaranya merupakan merupakan pelaku industri kreatif subsektor kerajinan, yang berada di posisi kedua teratas setelah kuliner. Output produk dari para pengrajin dipasarkan secara individu, memanfaatkan media social, dan kenalan mereka. Ada pula yang memanfaatkan fasilitas berupa pasar-pasar tradisional dan ruang publik melalui kegiatan mingguan sebagai kesempatan dalam menjual dan memasarkan produk mereka. Akan tetapi, untuk menjangkau pasar yang lebih luas, ruang publik seperti car free day dan night market dirasa kurang cukup.

Lokasi Solo yang menjadi jalur strategis peghubung Semarang, Yogyakarta dan Surabaya menjadi aspek penting dalam proses perkembang kota di sektor perdagangan dan jasa. Keberadaan potensi akar tradisi yang dituangkan melalui kegiatan seni budaya dengan konsep-konsep menarik menjadi magnet penarik perhatian wisatawan untuk berkunjung. Dampaknya, roda perekonomian semakin berputar dan pembangunan infrastruktur semakin membaik, Kota Solo pun semakin layak kunjung. 
Kepala Dinas Kebudayaan dan

Pariwisata kota Solo, Widdi Srihanto mengatakan, "Selain memiliki daya tarik sebagai kota budaya dan pariwisata, Solo dinilai aman dan nyaman sehingga kerap dijadikan tempat penyelenggaraan MICE, ditambah lagi pada 2009, Kementrian Pariwisata dan Ekonomi Kreatif mencanangkan Kota Solo sebagai salah satu kota tujuan MICE (travel.kompas.com/read /2013/11/11/1044316/Solo.Andalkan.Wisata.

Jasa - diakses 23 maret 2016)." Hingga saat ini kegiatan MICE di Solo diakomodasi oleh hotelhotel. Akan tetapi, kapasitas ruang yang terbatas tidak memungkinkan untuk kegiatan-kegiatan dengan skala besar.

Kebijakan pemerintah melalui programprogram seperti eco cultural city, one village one product, dan kota konferensi internasional berbasis budaya lokal, merespon dan mendukung keberadaan potensi-potensi kota dalam rangka meningkatkan kualitas hidup masyarakat kota.

Penghadiran Solo Craft Gallery Expo ini merupakan upaya pewadahan hasil kerajinan bernilai seni budaya yang dimiliki masyarakat Solo, serta mendukung strategi pemerintah yang tertuang dalam visi pembangunan jangka menengah 2010-2015 Solo Eco-Cultural City "One Village, One Product" yang outputnya perlu difasilitasi, baik produk, maupun kegiatan yang berkaitan dengan pemasaran, penjualan, event, dan lain-lain. Selain itu Solo Craft Gallery Expo juga dapat menjadi tujuan wisata baru di Kota Solo, dengan menjadikan craft sebagai objek yang dapat menarik minat wisatawan untuk datang serta nilai tawar dalam City Branding. Dan menjadi wadah yang memfasilitasi kegiatan MICE bertaraf internasional.

Upaya menyeleraskan citra Kota Solo sebagai Kota budaya dengan citra bangunan Solo Craft Gallery Expo diwujudkan melalui arsitektur Jawa kontemporer. Arsitektur Jawa yang merupakan arsitektur hasil dari proses kehidupan masyarakat jawa dalam berkebudayaan, layak untuk diapresiasi keberadaannya sebagai suatu kekuatan arsitektur lokal yang diangkat dan dijadikan identitas kelokalan sebuah Kota.

\section{METODE}

\subsection{Metode Pengumpulan Data}

\subsubsection{Observasi}

Melakukan pengamatan langsung terhadap objek penelitian di lapangan dengan cara sebagai berikut:

1. Mengunjungi para pelaku kerajinan dan pekerja seni pertunjukan di Surakarta untuk mengetahui hal-hal terkait kerajinan yang mereka buat serta kegiatan yang dilakukan dalam memepersiapkan seni pertunjukan, mengetahui sejarahnya, proses pembuatan, proses pemasaran, apresiasi dari masyarakat luas, proses latihan, dll.

2. Mengunjungi galeri dan expo center sebagai preseden.

3. Wawancara

a. Melakukan interview kepada beberapa pengrajin, untuk menggali lebih dalam mengenai kerajinan yang kental dengan budaya, yang masih dipertahankan keberadaannya hingga saat ini.

b. Melakukan tanya jawab kepada pengelola bangunan galeri dan expo center untuk mengetahui tentang sistem pewadahan dan pelayanan yang ditawarkan.

4. Dokumentasi

Melakukan perbendaharaan visual, dengan cara sebagai berikut:

a. Mendokumentasikan foto proses pembuatan maupun hasil karya kerajianan yang siap dipasarkan serta mengetahui dengan jelas mengenai dimensi dan ukuran sebuah hasil karya kerajinan.

b. Mendokumentasikan beberapa bangunan galeri dan expo center sebagai studi preseden.

5. Studi Literatur

Melakukan pengumpulan informasi yang bersumber dari referensi (buku, media cetak dan media online) tentang program UNESCO The Creative City Network, Solo sebagai kota kreatif, ekonomi dan industri kreatif di Kota Solo, kegiatan expo, sistem pewadahan galeri, akrtapakktur tradisional Jawa, arsitektur kontemporer, arsitektur Jawa kontemporer.

\subsection{Metode Analisis}

Melakukan analisis data dan informasi yang sudah dikumpulkan untuk mengidentifikasi permasalahan dan menganalisis masalah tersebut ke arah pendekatan konsep perencanaan dan 
perancangan solo craft gallery expo. Data dan informasi tersebut dikaji dan digunakan dalam proses perencanaan dan perancangan melalui tiga tahap pemrograman, yaitu sebagai berikut.

1. Pemrograman fungsional

Menganalisis kegiatan, identifikasi pengguna, sruktur organisasi, area kegiatan, dan pensrtukturan pengguna dengan kegiatan pada solo craft gallery expo.

2. Pemrograman performansi

Menganalisis identifikasi kebutuhan dengan pengguna, atribusi lingkungan dengan pengguna, karakteristik respon lingkungan, dan potensi lingkungan untuk memperoleh performansi sistem ruang dan bangunan solo craft gallery expo.

3. Pemrograman arsitektur

Dilakukan untuk menganalisis tapak, ruang atau bangunan, dan tapak tapak solo craft gallery expo sesuai dengan efektifitas fungsi dan spesifikasi bangunan yang direncanakan.

\subsection{Metode Penyajian}

Penyajian hasil penelitian dilakukan melalui tulisan deskriptif konsep perencanaan dan perancangan solo craft gallery expo. Selain itu disertai juga dengan tabel dan gambar informatif dalam bentuk skema, ilustrasi dan sketsa ide yang komunikatif.

\section{ANALISIS}

3.1 Analisis Peruangan dan Sistem Pewadahan

Bertujuan untuk mendapatkan pola kegiatan dan kebutuhan ruang pengguna pada Solo Craft Gallery Expo yang terdiri dari kegiatan pengunjung, pengelola, komunitas perajin, volunteer, penyelenggara kegiatan dan pengguna lainnya.

\subsubsection{Analisis Peruangan}

\subsubsection{Pengguna}

Adapun ruang-ruang yang dihasilkan dari pengguna dan kegiatan, antara lain sebagai berikut:

1. Komunitas Pengrajin yang tergabung dalam jejaring UMKM Solo

2. Kurator

3. Volunteer

4. Tour guide
5. Pengelola galeri dan expo

6. Pengunjung galeri dan peserta kegiatan expo

7. Petugas servis

\subsubsection{Sistem Pewadahan}

Sistem pewadahan yang menghasilkan kebutuhan ruang pada solo craft gallery expo adalah sebagai berikut:

1. Area penerima

2. Area galeri

3. Area pengelola

4. Area expo

5. Area servis

\subsection{Analisis Tapak}

Berikut ini merupakan beberapa pertimbangan potensi dalam pemilihan tapak.

1. Berada di wilayah peruntukan pemerintahan, pariwisata budaya, perdagangan dan jasa.

2. Keberadaan dengan eksisting yang mendukung, berupa perkantoran, fasilitas transportasi (bandara, terminal dan stasiun) serta fasilits penginapan,

3. Lokasi tapak yang terletak di area suburban, (perbatasan antara Kota Solo dengan Kabupaten Karanganyar) menjadikan area ini tidak padat kendaraan yang menyebabkan kemacetan, sehingga memberikan kemudahan dalam pencapaian menuju lokasi.

4. Jalan Adi Sucipto yang berada di depan tapak diklasifikasikan sebagai jalan kelas dua, yaitu jalan arteri yang dapat dilalui kendaraan bermotor dengan muatan sumbu terberat hingga 10 ton. Hal ini mendukung keberadaan kegiatan pameran yang diwadahi bangunan dalam hal transportasi pengadaan barang-barang yang dipamerkan.

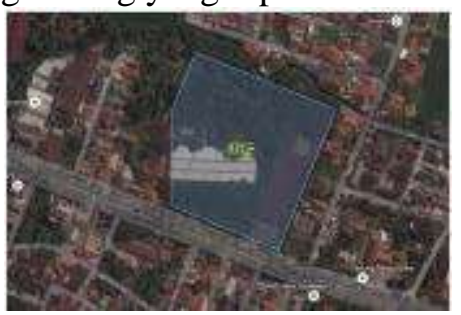

Gambar 1. Tapak Terpilih (Google Earth, 2016)

Lokasi tapak terpilih berada di Jl. Adi Sucipto No.178, Karangasem, Laweyan, Kota 
Surakarta, Jawa Tengah 57144. Tapak memiliki bentuk persegi yang terpotong pada sisi selatan dan sisi barat yang menjadikan bentuknya trapesium siku-siku yang terbalik, dengan jalan di sisi bagian selatan. Tapak memiliki luas area sebesar 37.490,845 $\mathrm{m}^{2}$. Eksisting tapak berbatasan dengan Kali Gajah Putih (utara), Jalan Adi Sucipto, Kantor DPRD Surakarta (selatan), dan Pemukiman Penduduk (timur dan barat).

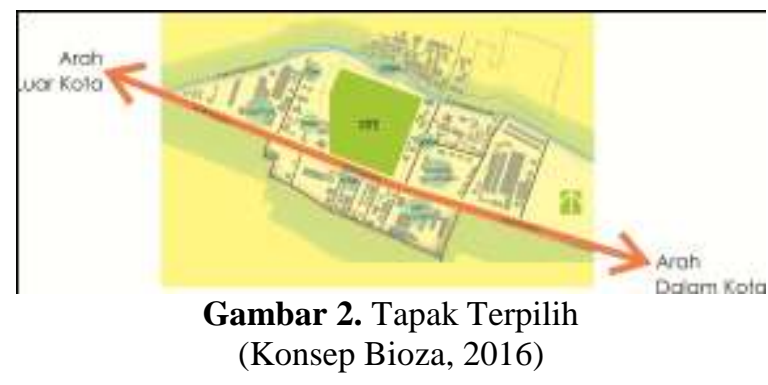

3.3 Analisis Pengolahan Tapak

3.3.1 Analisis Pencapaian, View dan Orientasi Bangunan

Bertujuan untuk mendapatkan pola pencapaian yang mudah diakses, yaitu dengan menempatkan posisi pintu masuk dan letak fasilitas kelompok pewadahan secara tepat. Adapun pertimbangan dalam mengolah pencapaian, antara lain sebagai berikut:

1. Keberadaan jalan Adi Sucipto pada bagian selatan tapak yang merupakan satu-satunya jalan yang dapat dimanfaatkan sebagai akses masuk dan keluar.

2. Tapak berada di bagian utara jalan, menjadikan posisi tapak berada di sisi kanan jalan jika diakses dari arah dalam Kota, sehingga pencapaian menuju tapak dilakukan dengan menyebrangi jalan. Hal ini memungkinkan adanya penumpukan kendaraan saat akan menyebrang masuk ke dalam tapak.
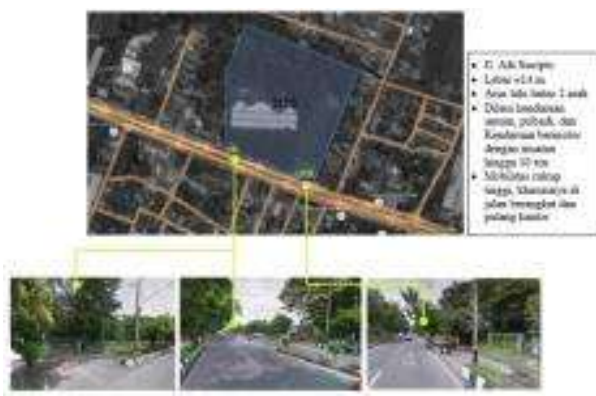

Gambar 3. Pola pencapaian ke tapak
(Google Earth, 2016)

Jalan Adi Sucipto merupakan satusatunya jalan yang dapat dimanfaatkan sebagai jalur masuk dan keluar pada tapak ini. Untuk merespon kondisi ini, dilakukan pemisahan melalui pemecahan sirkulasi dalam tapak bagi pengunjung dan pengelola. Akan tetapi jalur masuk Main Entrance untuk pengunjung, dan Side Entrance untuk pengelola tetap melalui jalur yang sama, begitu juga untuk jalur keluar dari tapak.

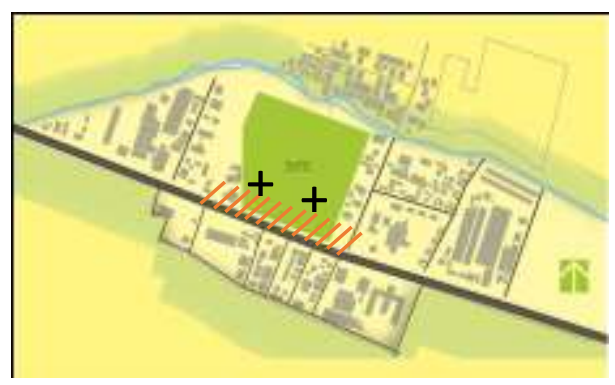

Gambar 4. Potensi View Terbaik (Analisa Bioza, 2016)

Area yang memiliki potensi view terbaik adalah area selatan tapak yang bersentuhan langsung dengan Jalan Adi Sucipto. Potensi ini mempengaruhi orientasi bangunan dan zoning sesuai dengan pengelompokan kegiatan. Untuk orientasi, mengoptimalkan ekspos bangunan ke arah luar melalui pengolahan tampilan fasad bangunan. Untuk zoning, pada area ini akan ditempatkan area yang bersifat publik.

Untuk orientasi bangunan, akan diarahkan ke arah selatan menghadap Jalan Adi Sucipto, yang memiliki potensi view terbaik ke dalam maupun ke luar tapak. Pengolahan orientasi terhadap tapak mempertimbangkan pergerakan kedatangan pengunjung, melibatkan aspek visual sehingga pengunjung dapat mengetahui dengan jelas lokasi tapak beserta keberadaan pintu masuk.

\subsubsection{Analisis Klimatologis}

Analisis klimatologis bertujuan untuk mengamati kemudian mendapatkan respon desain terhadap pergerakan matahari dan pergerakan udara pada lokasi tapak. Dengan mempertimbangkan keberadaan lokasi tapak dan lingkungan sekitarnya yang dapat mempengaruhi kondisi tapak.

\subsubsection{Pergerakan Matahari}




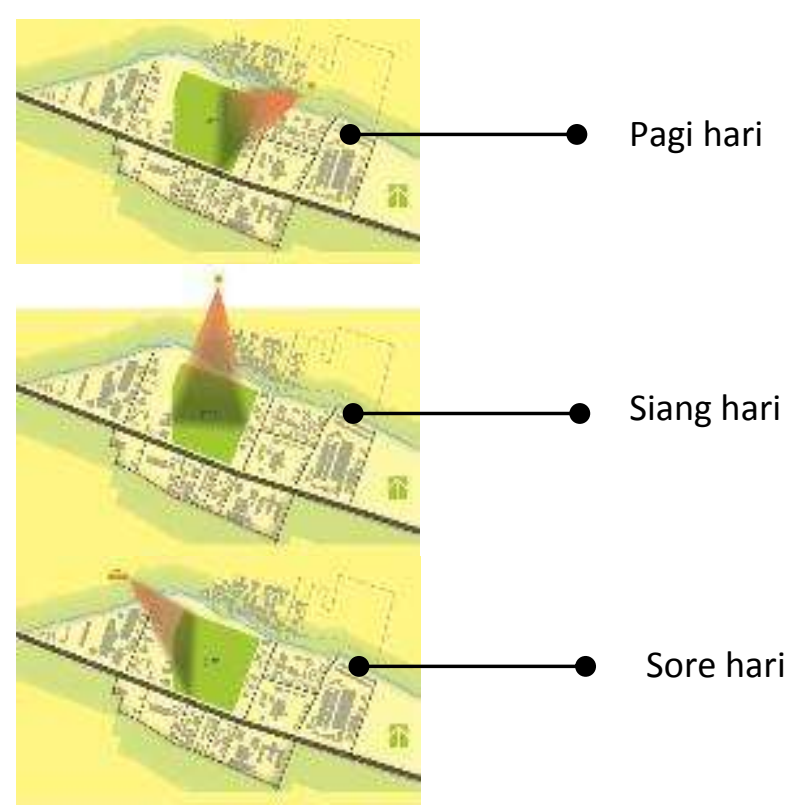

Gambar 5. Pergerakan Matahari (Analisa Bioza, 2016)

Sinar matahari sebagai pencahayaan alami pada tapak. Sinar yang mengenai sisi timur pada pagi hari akan menimbulkan bayangan pada sisi barat, dapat memberikan tekstur dan suasana ruang. Masuknya sinar matahari dapat melalui bukaan-bukaan berupa kisi-kisi, ventilasi dan jendela. Pada siang hari, sinar matahari dibiarkan masuk melalui area terbuka antar bangunan, sedangkan pada sore hari, sinar matahari yang mengenai sisi barat tapak akan menimbulkan bayangan pada sisi timur. Sama halnya dengan sinar matahari pagi hari, sinar matahari sore dapat dimanfaatkan dalam memberikan tekstur dan suasana ruang, akan tetapi sifat silau dari matahari sore perlu diperlakukan dengan baik.

Radiasi panas matahari menimbulkan ketidaknyamanan pada bangungan, sehingga dibutuhkan upaya agar tidak terjadi ekspos langsung secara berlebihan pada permukaan dinding yang terpapar sinar matahari, yaitu sisi timur (pada pagi hari) dan sisi barat (pada sore hari). Hal ini disiasati dengan upaya memperkecil bidang yang bersentuhan dengan sinar matahari sehingga, penyerapan panas matahari ke dalam ruang melalui bidang dinding menjadi lebih rendah. Selain itu penggunaan vegetasi sebagai barrier dan permukaan air pada sisi yang sama sebagai penyerap panas.

\subsubsection{Pergerakan Udara}

Tapak terpilih diapit Kali Gajah Putih dan jalan adi sucipto pada sisi utara dan selatan, sedangkan pada sisi timur dan barat merupakan permukiman penduduk. Tidak adanya bangunan tinggi di lingkungan tapak menyebabkan aliran udara dari yang datang dari segala arah tanpa terhalang apapun. Keberadaan peopohonan yang ditanam di tepi jalan, menjadi filter udara yang masuk ke tapak. Keleluasaan pergerakan angin ini perlu diperlakukan dengan baik agar tidak masuk secara berlebihan ke dalam bangunan. Untuk itu diperlukan upaya pengendalian angin dengan cara diperlambat, dipecah, dan dibelokkan, melalui penataan masa bangunan, serta pemanfaatan vegetasi berupa pohon-pohon dan perdu.

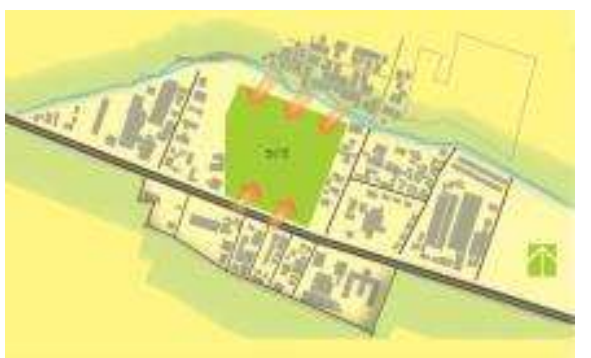

Gambar 6. Arah Pergerakan Udara (Analisa Bioza, 2016)

Tatanan Massa yang terdiri dari beberapa bangunan, mengoptimalkan pergerakan udara dalam bangunan. Membiarkan ruang terbuka hijau diantara massa bangunan mampu menciptakan iklim mikro yang baik. Selain itu penggunaan jenis bukaan yang tepat dapat menjadi device dalam mengendalikan aliran udara.

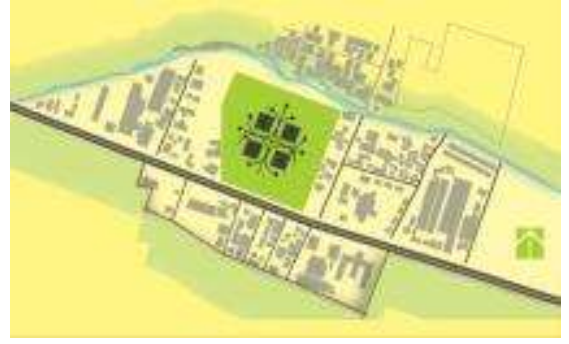

Gambar 7. Pergerakan udara antar Massa Sumber: Analisa Bioza, 2016

\subsection{Analisis Bentuk dan Tatanan}

Tata Massa mengikuti pola tata ruang rumah jawa yang terdiri dari beberapa Massa 
dalam satu lingkungan, membiarkan terjadinya interaksi antara ruang luar (lingkungan alam) dengan ruang dalam (lingkungan buatan). Karakteristik tatanan ruang pada rumah jawa merupakan kawasan simetris, dengan sumbu kosmis horizontal berupa empat arah mata angin sebagai datum utara-selatan dan timur-barat, serta sumbu vertikal yang terletak titik pusat pertemuan keempat arah mata angin tersebut, yang dalam terminologi Jawa dikenal dengan papat kiblat lima pancer.

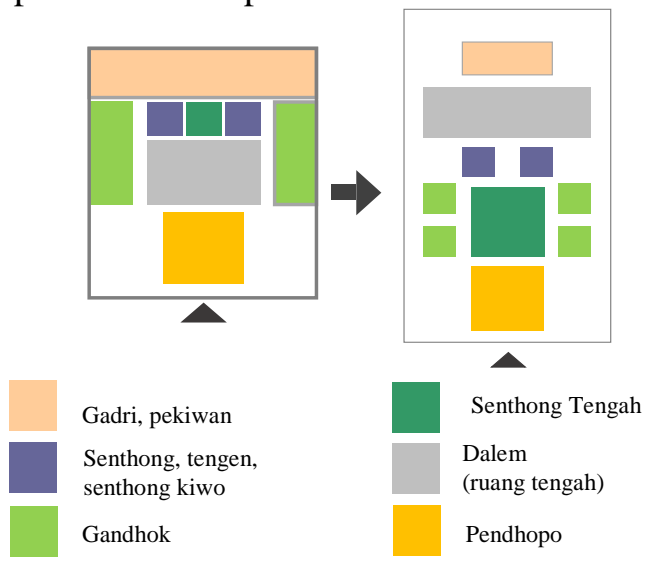

Gambar 8. Analisis Tata Massa (Analisa Bioza, 2016)

\subsection{Analisis Bentuk Bangunan}

Bangunan tradisional jawa terdiri dari elemen kepala (rangka dan penutup atap), badan (tiang atau saka, dinding, pintu, jendela, ventilasi) dan kaki (pondasi, lantai, umpak).

\subsubsection{Kepala (rangka dan penutup atap)}

Penggunaan elemen atap akan dibedakan menjadi beberapa bentuk atap, dengan tujuan membedakan sesuai dengan fungsi pewadahan kegiatan dalam bangunan.

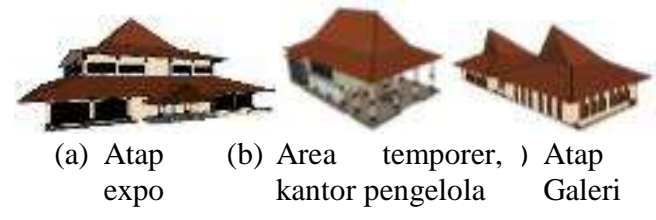

Gambar 9. Perbendaan bentuk atap (Konsep Bioza, 2017)

\subsubsection{Badan (dinding, tiang, pintu, jendela) 3.5.2.1 Dinding.}

Pandangan manusia jawa yang percaya pada kekuatan kosmos, yang berasal dari lingkungan alam, memandang perlu adanya pembatas yang tegas antara ruang luar dengan ruang dalam. Batas yang paling kuat adalah dinding pemisah, sedangkan yang lain adalah berupa perbedaan ketinggian lantai. Untuk tetap memunculkan keterkaitannya dengan unsur alam, penggunaan material mengutamakan jenis material yang berasal dari alam, seperti kayu/papan, bambu, serta dinding pasangan batu bata.

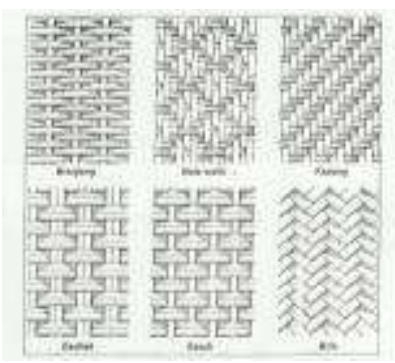

Gambar 10. Anyaman Bambu untuk Dinding (Jogja Heritage Society, hal.53)

\subsubsection{Tiang.}

Ekspos tiang, sebagai elemen pembentuk ruang, diaplikasikan pada bangunan pendopo dan area pameran temporer.

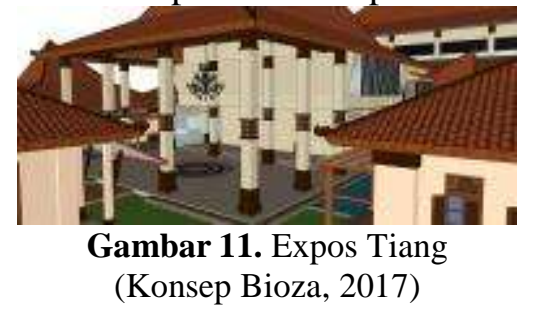

\subsubsection{Pintu dan Jendela.}

Perletakan pintu utama pada rumah jawa biasanya diletakkan secara simetris di depan rumah, pintu diletakkan di tengah, diapit jendela di sisi kiri dan kanan. Dari segi proporsi, tinggi pintu harus diperhatikan sehingga terlihat tegak lurus dan kokoh, ukurannya disesuaikan dengan tinggi tiang mulai dari atas lantai sampai ke blandar. Jumlah daun pintu dan jendela rata-rata dua buah (kupu tarung). Keberadaan pintu dan jendela berfungsi sebagai device masuknya udara ke dalam bangunan. Pintu dan Jendela. Perletakan pintu utama pada rumah jawa biasanya diletakkan secara simetris di depan rumah, pintu diletakkan di tengah, diapit jendela di sisi kiri dan kanan. Dari segi proporsi, tinggi pintu harus diperhatikan sehingga terlihat tegak lurus dan kokoh, ukurannya disesuaikan dengan tinggi tiang mulai dari atas lantai sampai ke blandar. Jumlah daun pintu dan jendela rata-rata dua buah (kupu tarung). Keberadaan pintu dan 
jendela berfungsi sebagai device masuknya udara ke dalam bangunan.

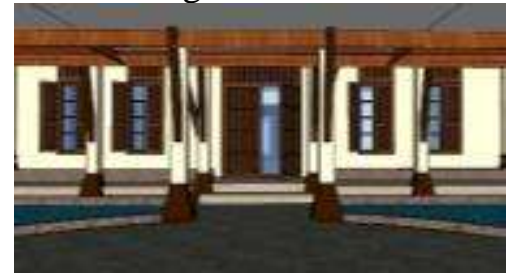

Gambar 12. Pintu dan Jendela Kupu Tarung (Konsep Bioza, 2017)

\subsubsection{Kaki (pondasi, lantai, umpak)}

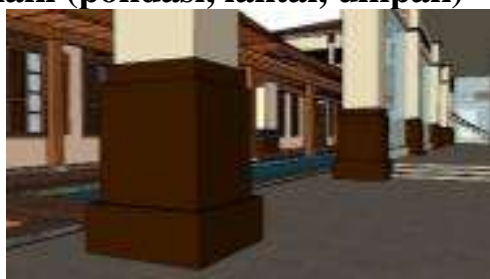

Gambar 13. Umpak

(Konsep Bioza, 2017)

\section{KESIMPULAN}

Konsep perencanaan dan perancangan Solo Craft Gallery Expo ini menerapkan Arsitektur Jawa Kontemporer untuk menyelaraskan citra bangunan dengan citra Kota Solo sebagai Kota budaya. Strategi ini merupakan upaya dalam mengangkat nilai-nilai kebudayaan dan kemasyarakatan. Keberadaan Arsitektur jawa yang merupakan hasil dari proses kehidupan masyarakat jawa dalam berkebudayaan, layak untuk diapresiasi sebagai suatu kekuatan arsitektur lokal yang dapat dijadikan identitas sebuah Kota.

Pemunculan unsur arsitektur Jawa pada bangunan tampak dari ornamen pada atap seperti, ornamen rete-rete (Gambar 14), ornamen makhuto (Gambar 15), ornamen krapyak (Gambar 16). Kemudian penataan massa bangunan yang terdiri dari beberapa massa dalam satu lingkungan, serta perbedaan bentuk atap terlihat pada perspektif eksterior (Gambar 17) dan fasad droping area (Gambar 18). Serta penghadiran unsur alam seperti kolam air dan tanaman teratai yang diletakkan di ruang luar antar bagunan pengelola dan galeri, serta tanaman rambat di atas selasar galeri (Gambar 19).

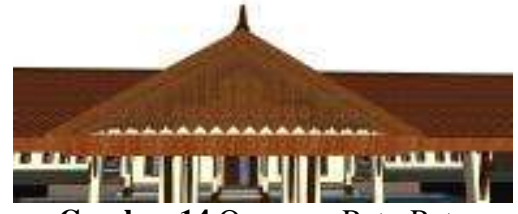

Gambar 14.Ornamen Rete-Rete

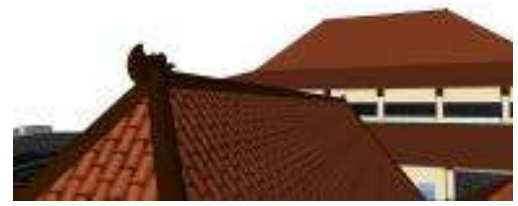

Gambar 15. Ornamen Makutho

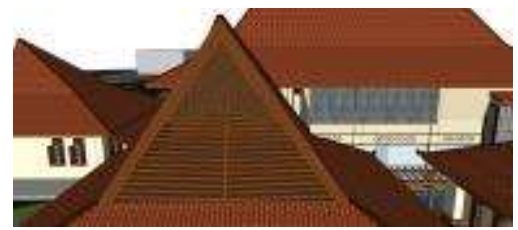

Gambar 16. Ornamen Krapyak

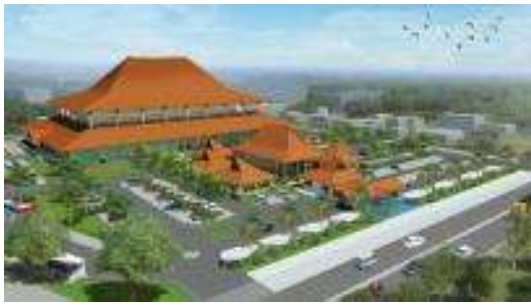

Gambar 17. Perspektif Eksterior

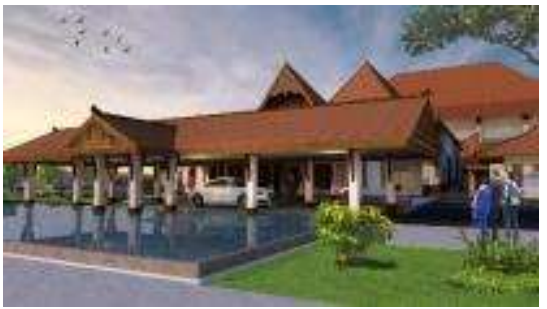

Gambar 18. Fasad Droping area

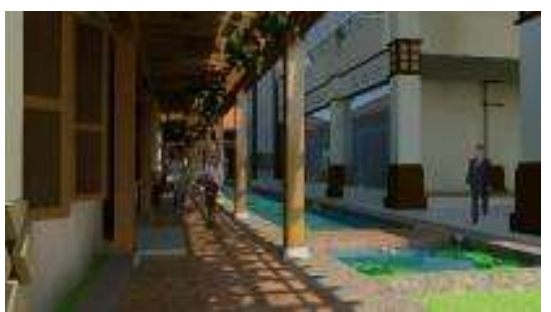

Gambar 19. Selasar pada Galeri

\section{REFERENSI}


Arsitektura, Vol. 15, No.1, April 2017: 269-276

Jogja Heritage Society. 2007. Pedoman Pelestarian Bagi Pemilik Rumah Kawasan Pusaka Kotagede, Yogyakarta, Indonesia. (tidak diterbitkan). Organization of Kotagede Heritage District Management (OPKP Kotagede). 